\title{
OESTROGENIC FUNCTION IN POSTMENOPAUSAL WOMEN
}

\author{
G. A. DOVE, * F. MORLEY, $\dagger$ A. BATGHELOR \\ AND S. F. LUNNS \\ * 211 North End Road, London, W.14, \\ $\dagger$ Charing Cross Group of Hospitals, London, \\ $\ddagger$ G. D. Searle and Company, High Wycombe, and \\ $\$$ M.R.C. Clinical Endocrinology Unit, Edinburgh \\ (Received 18th November 1969, revised 17th Fune 1970)
}

\begin{abstract}
Summary. Results are presented of a study of healthy European women who were more than 2 years beyond the menopause. In these subjects, oestrogenic function was assessed by cytological examination of vaginal smears and by estimation of the output of 'total oestrogens' in the urine.

'Oestrogenic activity', as assessed by maturation and karyopyknotic indices, could be detected in more than $75 \%$ of the women (which correlates with previously recorded data).

In all subjects studied, the measured urinary oestrogen excretion was low, levels being well below the range normally encountered in women during their reproductive life.

No correlation could be demonstrated between oestrogen excretion and age or cytological indices.
\end{abstract}

\section{INTRODUCTION}

It is important to evaluate the oestrogenic function of the individual at the time of the menopause and beyond in order to determine on what criteria the need for replacement therapy can be assessed. Such an assessment can be made either by studies involving vaginal cytology or by the estimation of oestrogens in the urine.

The aim of the present work was to examine the relationship between the maturation of the vaginal epithelium and the 24-hr urinary output of the three classical oestrogens-oestrone, oestradiol-17 $\beta$ and oestriol-and to correlate these parameters with the clinical data.

\section{MATERIALS AND METHODS}

\section{Clinical}

The sixty-eight women reported in this study were selected at random from a group of normal healthy menopausal and postmenopausal subjects examined in a general practice in London. In order to avoid inclusion of women in

The Editor regrets to report that the death of Dr Francis Morley occurred in July 1969. 
whom ovarian activity persisted, the women selected were all 2 or more years postmenopausal and were not receiving any medication at the time of investigation. A cervical smear was taken after a general examination.

\section{Hormone assay}

Urine was collected from twenty-seven postmenopausal subjects. No preservative was added to the samples which were collected over a period of 24 or $48 \mathrm{hr}$. They were stored at $4^{\circ} \mathrm{C}$ and assayed within a few days or deep frozen $\left(-20^{\circ} \mathrm{C}\right)$ to await assay at a later date. The method of estimation was essentially that of Brown, MacNaughtan, Smith \& Smyth (1968), including the saponification step described by Brown, Bulbrook \& Greenwood (1957).

In five postmenopausal subjects, oestrogen assays were repeated at a later date using the same method. In one of the latter group, parallel assays using both the spectrophotometric and spectrophotofluorimetric end-points were carried out. It was, therefore, possible to compare the results obtained by the method of Brown et al. (1957) with those of the Brown et al. (1968) procedure.

\section{Cvtological methods}

Vaginal smears, obtained from the posterior fornix pool with an Ayre's spatula or pipette, were taken on two occasions near, or at, the time of the urine collection. All the smears were fixed with carbowax, stained by the method of Papanicolaou \& Traut (1943) and examined for atypical cells. Cytology of the vaginal smear was undertaken for hormonal assessment of oestrogenic activity only if infestation and inflammation were absent and spermatozoa were not present. The karyopyknotic index (KI) was calculated from 200 cells, counting the number of pyknotic squames having structureless opaque nuclei of less than $6 \mathrm{~m} \mu$ diameter. Using the maturation index (MI), the following maturation values (MV) were calculated: superficial squames, 1.0 ; intermediate cells, 0.5 ; and parabasal cells, 0.0 . This is a modification of the classification of Meisels (1966) and was used in a preliminary report by Dove (1968). As reported above, the MV has now been accepted as a standard by the second Tutorial on Hormonal Cytology (Weid, 1968) where it was shown that the MV, as computed from the MI, is constant for any one slide examined as measured by a number of different investigators.

\section{RESULTS}

Table 1 gives the initial data on the twenty-seven women in whom oestrogen assays were conducted.

The values for 'total oestrogen' remained low as compared with those demonstrated in women during the menstrual phase of the normal cycle (Loraine \& Bell, 1966). There was no significant relationship between age and oestrogen excretion $(\mathrm{r}=-0.275, \mathrm{n}=27, P=\mathrm{NS})$. Similarly, no relationship between total oestrogen values and time since the completion of menopause could be demonstrated. No significant correlation was noted between oestrogen excretion and the cytological indices (for $\mathrm{MV}, \mathrm{r}=0.313, P=\mathrm{NS}$; for $\mathrm{KI}$, $\mathrm{r}=-0.034, P=\mathrm{NS}, \mathrm{n}=27$ in both cases). 


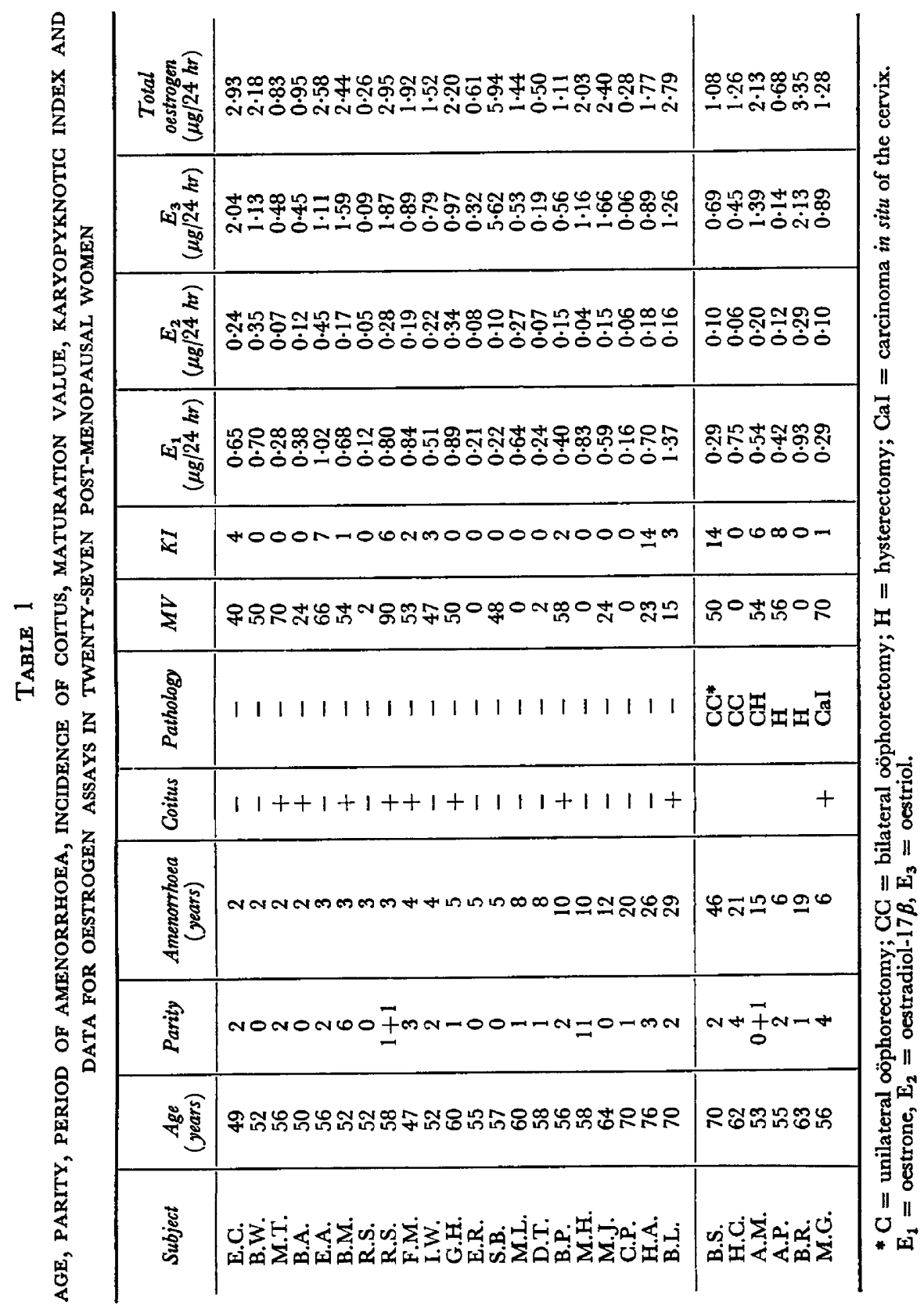


Repeated oestrogen assays in these subjects gave similar results to those found in the initial assay. Vaginal smears taken from some subjects on different occasions showed that considerable changes could occur in the cytological indices, whereas in others they remained constant.

Table 2 shows the results obtained in one subject from the two methods of oestrogen assay mentioned above. Assays were carried out in duplicate on two

TABLE 2

DATA IN ONE POSTMENOPAUSAL SUBJECT SHOWING GOMPARISON OF TWO METHODS OF OESTROGEN ASSAY

\begin{tabular}{|c|c|c|c|c|c|c|c|c|}
\hline \multirow{3}{*}{ Collection no. } & \multicolumn{8}{|c|}{ Assay method } \\
\hline & \multicolumn{4}{|c|}{$\begin{array}{c}\text { Spectrophotofluorimetric } \\
(\mu g / 24 h r)\end{array}$} & \multicolumn{4}{|c|}{$\begin{array}{l}\text { Spectrophotometric } \\
(\mu g / 24 h r)\end{array}$} \\
\hline & $E_{1}$ & $E_{2}$ & $E_{3}$ & Total & $E_{1}$ & $E_{2}$ & $E_{3}$ & Total \\
\hline 1 & $\begin{array}{l}0 \cdot 31 \\
0 \cdot 26\end{array}$ & $\begin{array}{l}0 \cdot 12 \\
0 \cdot 10\end{array}$ & $\begin{array}{l}4 \cdot 31 \\
4 \cdot 05\end{array}$ & $\begin{array}{l}4 \cdot 74 \\
4 \cdot 41\end{array}$ & $\begin{array}{l}2 \cdot 3 \\
2 \cdot 2\end{array}$ & $\begin{array}{l}1.8 \\
0.8\end{array}$ & $\begin{array}{l}7 \cdot 6 \\
6 \cdot 0\end{array}$ & $\begin{array}{r}11 \cdot 7 \\
9 \cdot 0\end{array}$ \\
\hline 2 & $\begin{array}{l}0 \cdot 22 \\
0.21\end{array}$ & $\begin{array}{l}0 \cdot 10 \\
0.09\end{array}$ & $\begin{array}{l}5 \cdot 56 \\
5 \cdot 78\end{array}$ & $\begin{array}{l}5 \cdot 88 \\
6 \cdot 08\end{array}$ & $\begin{array}{l}2 \cdot 3 \\
1 \cdot 5\end{array}$ & $\begin{array}{l}0.0 \\
0.0\end{array}$ & $\begin{array}{l}6 \cdot 8 \\
7 \cdot 6\end{array}$ & $\begin{array}{l}9 \cdot 1 \\
9 \cdot 1\end{array}$ \\
\hline
\end{tabular}

$\mathrm{E}_{1}=$ oestrone, $\mathrm{E}_{2}=$ oestradiol-17 $\beta, \mathrm{E}_{3}=$ oestriol.

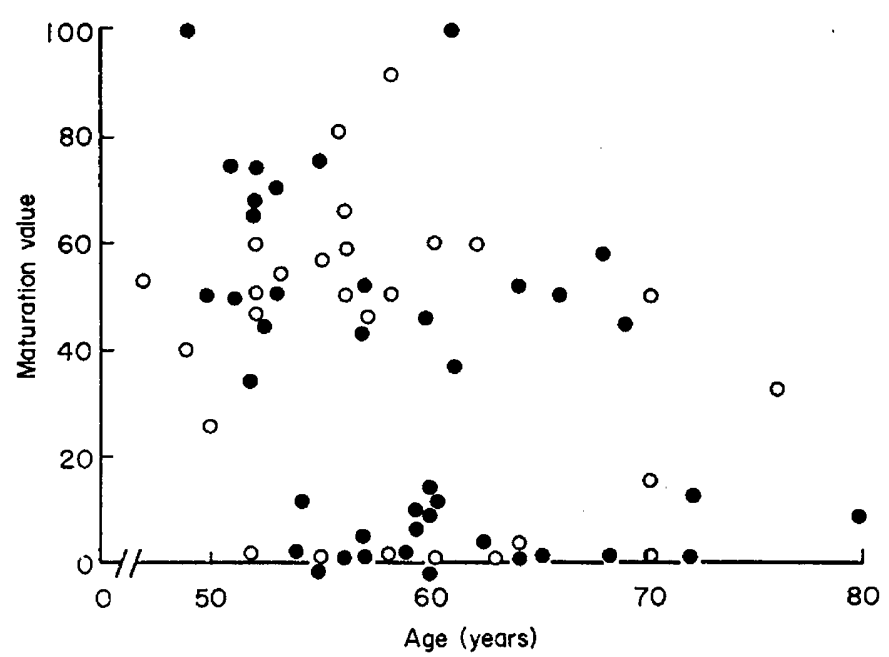

Text-pig. 1. The correlation between age and the maturation value in the vaginal smear in sixty-eight subjects: $O$, women in whom total oestrogen excretion was estimated; $\bullet$, women in whom oestrogen assays were not performed.

separate urine collections. The oestriol output, as measured by both methods, was high as compared with all other subjects in the series; however, the values for oestrone and oestradiol- $17 \beta$ were in the same range as in the other women. The results obtained by the spectrophotometric method were higher than those found by the spectrophotofluorimetric technique, except for the reading for oestradiol in one sample. 
Initial MV and KI values were plotted against age in the sixty-eight subjects. The absence of correlation between age and MV is apparent (Text-fig. 1), both for women for whom oestrogen assays were or were not performed $(\mathrm{r}=-0.327 ; \mathrm{n}=27 ; P=\mathrm{NS})$. The data in Text-fig. 1 do, however, suggest that the maturation values may divide into two groups; one generally above 35

TABLE 3

EFFECT OF PARITY ON THE MATURATION

VALUE OF THE VAGINAL EPITHELIUM

\begin{tabular}{l|c|c}
\hline \multicolumn{1}{c|}{ Maturation value } & $\begin{array}{c}\text { Atrophic } \\
(<31)\end{array}$ & $\begin{array}{c}\text { Intermediate } \\
(>31)\end{array}$ \\
\hline No. of women & 32 & 36 \\
Mean MV & 5.6 & 54.8 \\
\hline $\begin{array}{l}\text { No. of pregnancies } \\
\text { Two or less } \\
\text { Three or more }\end{array}$ & 20 & 31 \\
\hline
\end{tabular}

$\chi^{2}=3.86 ; P<0.05 ;$ d.f. $=68$.

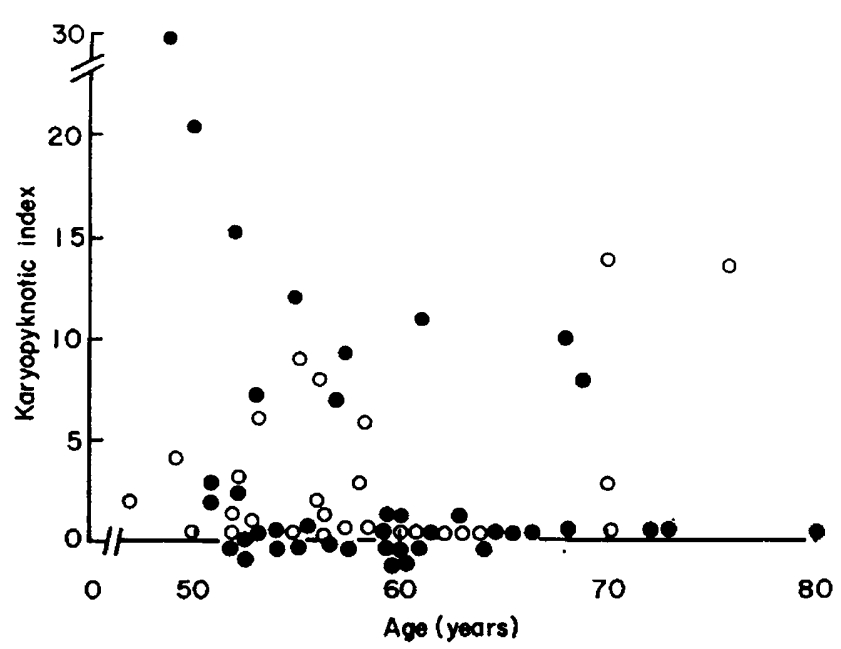

TEXT-FIG 2. The correlation between age and the karyopyknotic index in the vaginal smear in sixty-eight postmenopausal subjects; $O$, women in whom total oestrogen excretion was estimated; $\bullet$, women in whom oestrogen assays were not performed.

and one generally below 15 . Application of a simple cluster analysis technique (i.e. separating the groups in such a way that each MV reading is nearer the mean of its own group than that of the other group) estimated a boundary at an MV of 31. The difference between the means of these groups was sufficiently high to suggest that they referred to two separate clusters of results and not merely to one population split into two $(P<0.001)$. An association was found between parity and MV, greater parity being associated with MV values below the estimated boundary of 31 (see Table 3 ). 
In the twenty-seven women in whom oestrogen assays were performed, a low but significant correlation was demonstrated between $\mathrm{KI}$ and age $(\mathrm{r}=$ $0.394 ; \mathrm{n}=27 ; P=0.05)$. The $\mathrm{KI}$ as determined in all sixty-eight patients was low, i.e. below 20 . Of these, only $25 \%$ of the values exceeded 5 (Text-fig. 2).

\section{DISCUSSION}

In twenty-seven subjects, both cytological indices and urinary oestrogen output were examined. In a further forty-one women, cytological indices alone were studied. The overall conclusion to emerge from this investigation was that no correlation existed between MV and KI and the output of either total or individual oestrogens. Other workers have observed a similar result. Charles, Bell, Loraine \& Harkness (1965), in a study of patients with endometrial carcinoma, observed that cytological indices alone provided an unreliable estimate of the oestrogenicity of body fluids. Frampton (1966), who studied a variety of abnormal gynaecological conditions, failed to demonstrate a correlation between $\mathrm{KI}$ and urinary oestriol excretion.

Differing results were obtained by Young, Bulbrook \& Greenwood (1957) and Procopé (1969). Young et al. (1957), in an attempt to determine the levels of oestrogen in the blood, demonstrated that different cytological indices were correlated with differing levels of urinary oestrogen output. The standard deviations for each group were wide, however, and the authors concluded that the overall statistical correlation was of little practical value. Procopé (1969) examined women before bilateral oöphorectomy. He found a positive correIation to exist between the two 'indicators' of endogenous oestrogen production studied (total urinary oestrogen and vaginal cytology), though the levels of each oestrogen were somewhat high, being within the range encountered in normally menstruating women. Johannisson, Gemzell \& Diczfalusy (1961) have demonstrated a highly significant correlation between KI and the logarithm of the sum of 'total' urinary oestrogen. Their findings were compiled from five young amenorrhoeic women who had been stimulated with a single dose of a human pituitary follicle-stimulating preparation. The high urinary oestrogen excretions resulting from this manner of stimulation are, however, never reached under normal conditions in non-pregnant women.

One factor which may have contributed to the differing results reported in these studies concerns the actual method of assay employed. Thus, Young $e t$ al. (1957) used the method described by Brown (1955) for the estimation of oestrogens in urine. It is now recognized that this technique has limitations with respect to specificity when low-titre urines are assayed (see Loraine \& Bell, 1966). Thijssen \& Veeman (1968), using gas liquid chromatography, examined thirty-five Dutch women and obtained a mean value for each oestrogen which was four times higher than that which we have demonstrated. In the present investigation, the technique of Brown et al. (1968), which was used for oestrogen determination, had a sensitivity considerably higher than that of his original method (Brown, 1955). This might well be expected to yield estimates which approximate more closely to the true value.

A second factor which may have contributed to the differing results obtained 
by Young et al. (1957) and by Procopé (1969) concerns the type of subject studied in the various investigations. Rubenstein \& Duncan (1941) claim that a correlation exists between vaginal cytological indices and urinary oestrogen output as measured by bioassay (Smith, Smith \& Gavian, 1959; Rakoff, 1961). It should, however, be emphasized that bioassay methods for oestrogens possess great inherent difficulties, especially as regards the precision of the results obtained (Emmens, 1939; Loraine, 1958). There is, therefore, no direct evidence that maturation of vaginal cytology relates to endogenous oestrogen levels in the body fluids of postmenopausal women.

Struthers (1956), however, found a wide distribution of oestrogenic activity as measured by vaginal cytology in women who had had a spontaneous menopause or a bilateral oöphorectomy (see also Meisels, 1966). The MV obtained from the sixty-eight women in the present study closely reflects the results quoted in these reports. On clinical examination, the women in this study could be separated into two groups depending on whether or not the vaginal epithelium was atrophic or intermediate. Statistical analysis of these groups suggests that women who had had three or more children were more likely to have an atrophic vaginal epithelium, despite the fact that the incidence of coitus at the time of examination was similar in each group.

From the results of the present study, it is concluded that neither total urinary oestrogen excretion nor vaginal cytology provide a useful guide to oestrogenic function in postmenopausal women, or a baseline from which hormonal replacement therapy can be determined. It would appear that the $\mathrm{MV}$ is a more consistent and precise parameter than the KI in postmenopausal women and a more useful measure from the point of view of further research.

\section{ACKNOWLEDGMENTS}

Thanks are due to Dr J. A. Loraine for his helpful advice and comment and to Mr M. A. Sheikh and other staff of the Gytological Department at Fulham Hospital. We would like to thank Dr G. R. Venning and Mr Derek Edwards of G. D. Searle \& Co. Ltd, High Wycombe, for their support and statistical advice, and Mr L. S. Jackson for his technical assistance.

\section{REFERENGES}

Brown, J. B. (1955) A chemical method for the determination of oestriol, oestrone and oestradiol in human urine. Biochem. 7. 60, 185.

Brown, J. B., Bulbrook, R. D. \& Greenwood, F. G. (1957) An additional purification step for a method for estimating oestriol, oestrone and oestradiol-17 $\beta$ in human urine. 7. Endocr. 16, 49.

Brown, J. B., MacNaughtan, G., Smrth, M. A. \& Smyth, B. (1968) Further observations on the Kober colour and Ittrich fluorescence reactions in the measurement of oestriol, oestrone and oestradiol. 7. Endocr. 40, 175.

Gharles, D., Bell, E. T., Loraine, J. A. \& Harkness, R. A. (1965) Endometrial carcinoma-endocrinological and clinical studies. Am. J. Obstet. Gynec. 91, 1050.

Dove, G. A. (1968) Organisation of a trial of long term menopausal replacement therapy. Clin. Trials, $5,103$.

Emmens, C. W. (1939) Reports on biological standards. V. Variables affecting the estimation of androgenic and oestrogenic activity. Spec. Rep. Ser. med. Res. Coun. No. 234.

Frampton, J. (1966) Increased oestrogen activity associated with postmenopausal bleeding. 7. Obstet. Gynaec. Br. Commonw. 73, 137. 
Johannisson, E., Gemzell, C.A. \& Diczfalusy, E. (1961) Effect of a single injection of human pituitary follicle-stimulating hormone on urinary estrogens and the vaginal smear in amenorrhoeic women. 7. clin. Endocr. Metab. 21, 1058.

LORAINE, J. A. (1958) The clinical application of hormone assay. Livingstone, Edinburgh.

LoRAINe, J. A. \& BELL, E. T. (1966) Hormone assays and their clinical application, 2nd edn. Livingstone, Edinburgh.

Meisels, A. (1966) The menopause: a cytohormonal study. Acta cytol. 10, 49.

Papanicolaou, G. N. \& Traut, H. F. (1943) Diagnosis of cancer of the uterus by the use of vaginal smears. The Commonwealth Fund, New York.

Procopt, B.-J. (1969) Studies on the urinary excretion, biological effects and origin of oestrogens in postmenopausal women. Acta endocr., Copenh. Suppl. 135.

Rakoff, A. E. (1961) Hormonal cytology in gynecology. Clin. Obstet. Gynec. 4, 1045.

Rubenstein, B. B. \& Duncan, D. R. L. (1941) A technic for assay of estrogen by evaluation of human vaginal smears and comparison with urinary estrogen assay on the mouse uterus. Endocrinology, 28, 911 .

Sмith, O. W., Smith, G. V. \& Gavian, N. G. (1959) Urinary estrogens in women. Am. J. Obstet. Gynec. 78, 1028.

Struthers, R. A. (1956) Post-menopausal oestrogen production. Br. med. F. i, 1331.

Thijssen, J. H. H. \& Veeman, W. (1968) A gas chromatographic method for the measurement of small amounts of estrogens in urine. Steroids, 11, 369.

Wern, G. L. (1968) Symposium on hormonal cytology (Chicago). Acta cytol. 12, 87.

Young, S., Bulbrook, R. D. \& GreENwood, F. G. (1957) The correlation between urinary oestrogen and vaginal cytology. Lancet, i, 350. 